\title{
POTENSI EKSTRAK KULIT BATANG BUNI (Antidesma bunius L. Spreng) UNTUK MENURUNKAN KADAR GLUKOSA DARAH TIKUS WISTAR HIPERGLIKEMIA
}

\author{
S. R. Santi, I. M. Sukadana dan N. W. I. Paramitha* \\ Program Studi Kimia FMIPA Universitas Udayana, Jimbaran Bali Indonesia \\ *Email: indahprmtha@gmail.com
}

\begin{abstract}
ABSTRAK
Buni (Antidesma bunius L. Spreng) merupakan salah satu tanaman obat tradisional yang kulit batangnya telah terbukti secara in vitro sebagai antidiabetes dengan mekanisme penghambat kinerja enzim $\alpha$ glukosidase. Penelitian ini bertujuan untuk mengetahui potensi ekstrak etanol kulit batang buni terhadap penurunan kadar glukosa darah tikus wistar yang diinduksi aloksan secara in vivo. Dua kelompok tikus kontrol $\mathrm{K}(+)$ dan $\mathrm{K}(-)$, serta tiga kelompok tikus perlakuan $\left(\mathrm{P}_{1}, \mathrm{P}_{2}\right.$, dan $\left.\mathrm{P}_{3}\right)$ masing-masing diberi ekstrak? dengan dosis 50, 100, dan $200 \mathrm{mg} / \mathrm{kg}$ BB diinduksi aloksan monohidrat dosis $150 \mathrm{mg} / \mathrm{kg} \mathrm{BB}$ untuk membuat tikus hiperglikemia. Pada hari ke-14 percobaan (postest) data rata-rata kadar glukosa darah diuji stastika menggunakan ANOVA dengan $\alpha=0,05$ serta uji lanjut Tamhane. Disimpulkan bahwa ekstrak etanol kulit batang buni dosis $200 \mathrm{mg} / \mathrm{kg}$ BB mampu menurunkan kadar glukosa darah mendekati kondisi normal bila dibandingkan dengan kontrol negatif $\mathrm{K}(-)$.
\end{abstract}

Kata kunci: antidiabetes, Antidesma bunius L. Spreng., KG-SM, kulit batang buni

\section{ABSTRACT}

Buni (Antidesma bunius L. Spreng) is one of the traditional medicinal plants whose stem bark has been proven in vitro as an antidiabetic by inhibiting the activity of the $\alpha$ glucosidase enzyme. This study aims to determine the potential of ethanol extract of buni bark to reduce blood glucose levels in wistar rats in vivo induced by alloxan. Two groups of control rats $\mathrm{K}(+)$ and $\mathrm{K}(-)$, and three groups of treated rats $\left(\mathrm{P}_{1}, \mathrm{P}_{2}\right.$, and $\left.\mathrm{P}_{3}\right)$ which were given the extract with a dose of 50,100, and $200 \mathrm{mg} / \mathrm{kg} \mathrm{BW}$ respectively, were induced with 150 $\mathrm{mg} / \mathrm{kg}$ BW alloxan monohydrate to make the rats hyperglycemic. On the 14th day of the trial (posttest) the average blood glucose level was tested using ANOVA with $\alpha=0.05$ and Tamhane's. It was concluded that the $200 \mathrm{mg} / \mathrm{kg} \mathrm{BW}$ ethanol extract of buni bark was able to reduce blood glucose levels to closer to the normal condition when compared to negative control K(-).

Keywords: antidiabetic, Antidesma bunius L. Spreng., GC-MS, stem barks

\section{PENDAHULUAN}

Hiperglikemia merupakan salah satu penyakit degeneratif sistem metabolisme yang dapat berakibat berbagai komplikasi. Faktor resiko penyakit ini adalah pola makan/gaya hidup, keturunan dan kurangnya aktivitas fisik (Wild et al., 2004). Pengobatan hiperglikemia dapat dilakukan melalui terapi farmakologi dengan pemberian insulin dan obat antidiabetes oral atau pemberian obat tradisional dengan potensi kandungan metabolit sekunder seperti: flavonoid, alkaloid, saponin, terpenoid (Elya $e t$ al., 2012), tanin (Sumadewi, 2011), steroid, polifenol dan antosianin (Gosh and Konishi., 2007) yang berperan dalam penghambatan transpor glukosa di usus (Kwon et al., 2007) sehingga kadar glukosa dapat menurun (Kiec et al., 2008). Terapi non farmakologi dilakukan melalui pengaturan berat badan (diet), pola makan dan olahraga (Atalay and Laaksonen, 2002; Lau and Harper, 2007)).

Buni (Antidesma bunius L.) adalah tumbuhan obat yang berpotensi sebagai bahan antihiperglikemia karena seluruh bagian tumbuhan ini menghasilkan senyawa metabolit sekunder seperti flavonoid, saponin, dan tanin serta ekstrak etanol dan etil asetat kulit batangnya terbukti serta secara in vitro menghambat kinerja $\alpha$-glukosidase dengan $\mathrm{IC}_{50}$ secara berturut-turut sebesar 3,90 ppm dan 5,73 ppm (Elya et al., 2012). Aktivitas antihiperglikemia kulit batang buni secara in vivo dari kulit batang buni perlu dilanjutkan untuk membuktikan potensinya sebagai obat 
penurun kadar glukosa darah pada tikus wistar yang diinduksi aloksan.

\section{MATERI DAN METODE}

\section{Bahan}

Bahan tumbuhan yang digunakan dalam penelitian adalah kulit batang buni (Antidesma bunius L. Spreng) yang diambil di daerah Tabanan pada bulan Maret 2017 dan telah dideterminasi di LIPI-UPT Balai Konservasi Tumbuhan Kebun Raya Eka Karya Bali. Bahan kimia yang digunakan antara lain etanol 96\%, akuades, aloksan monohidrat dosis $150 \mathrm{mg} / \mathrm{kg}$ BB dan pakan standar. Hewan coba yang digunakan yaitu tikus wistar jantan putih berumur 2-3 bulan dengan berat badan 200 $250 \mathrm{~g}$.

\section{Peralatan}

Peralatan yang digunakan dalam penelitian ini antara lain seperangkat alat gelas, penguap putar vakum (rotary vacuum evaporator), desikator, kertas saring, aluminium foil, alat sonde, glukometer Gluco $M$, stick Gluco $M$, gunting, sarung tangan, spuit injeksi $1 \mathrm{~mL}$

\section{Cara Kerja \\ Ekstraksi dan Rancangan Penelitian Pengukuran Kadar Glukosa Darah}

Serbuk kering kulit batang buni sebanyak $800 \mathrm{~g}$ dimaserasi dengan 3 x 1500 $\mathrm{mL}$ etanol $96 \%$ selama 24 jam. Ekstrak etanol digabung, lalu pelarutnya diuapkan dengan penguap putar vakum pada suhu $40{ }^{\circ} \mathrm{C}$ sehingga diperoleh ekstrak kental. Ekstrak kental diujikan efek penurunan kadar glukosa darah pada hewan coba dengan rancangan Randomized Control-Group Pretest-Posttest Design (Pocock, 2008; Suryabrata, 2011). Tikus jantan putih sebanyak 25 ekor berumur \pm 3 bulan dengan berat 200-250 g diaklimatisasi selama 1 minggu kemudian dikelompokkan sesuai dengan rumus Federer (1977) menjadi 5 kelompok perlakuan antara lain $\mathrm{K}(+)=$ kelompok kontrol positif (pemberian Glibenkamid $5 \mathrm{mg} / \mathrm{kg} \mathrm{BB}$ ); $\mathrm{K}(-)$ = kelompok kontrol negatif; $\mathrm{P}_{1}=$ ekstrak kulit batang buni dosis $50 \mathrm{mg} / \mathrm{kg} \mathrm{BB} ; \mathrm{P}_{2}=$ ekstrak kulit batang buni dosis $100 \mathrm{mg} / \mathrm{kg} \mathrm{BB}$; dan $\mathrm{P}_{3}=$ ekstrak kulit batang buni dosis $200 \mathrm{mg} / \mathrm{kg} \mathrm{BB}$.

Semua kelompok tikus diinjeksi dengan aloksan monohidrat dosis $150 \mathrm{mg} / \mathrm{kg}$ BB. Kadar glukosa darah diuji pada hari ke-0 (sebelum perlakuan), ke-3 (setelah injeksi aloksan), ke-10 (perlakuan) dan ke-17 (perlakuan) menggunakan stick Glucometer. Data kadar glukosa yang diperoleh dianalisis secara statistik dengan ANOVA menggunakan program SPSS versi 23 dengan $\alpha=0,05$.

\section{HASIL DAN PEMBAHASAN}

Hasil maserasi $800 \mathrm{~g}$ serbuk kering kulit batang buni dengan kadar air 7\% dengan etanol $96 \%$ menghasilkan ekstrak kental yang berwarna merah sebanyak 52,53 g. Hasil uji aktivitas penurunan kadar glukosa darah pada tikus wistar hiperglikemia akibat diinduksi aloksan, dipaparkan pada Gambar 1.

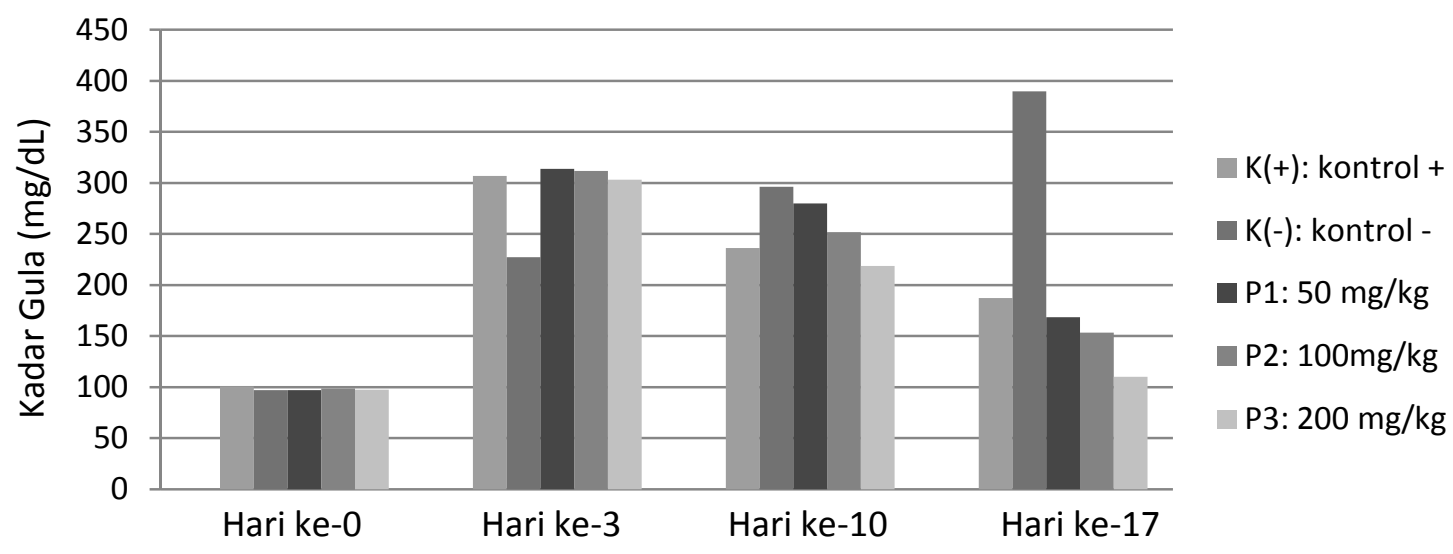

Gambar 1. Grafik Rata-rata Kadar Glukosa Darah Tikus Wistar 
Gambar 1 menunjukkan bahwa pada akhir percobaaan (postest) yaitu hari ke-17 (14 hari pemberian ekstrak), kelompok tikus dengan pemberian ekstrak etanol kulit batang buni dosis $50 \mathrm{mg} / \mathrm{kg}$ BB $\left(\mathrm{P}_{1}\right)$ memiliki kadar glukosa darah rata-rata sebesar $168.6 \pm 11.22$ $\mathrm{mg} / \mathrm{dL}$ atau penurunan kadar gula darah 221,2 $\mathrm{mg} / \mathrm{dL}$ bila dibandingkan dengan kelompok kontrol negatif $\mathrm{K}(-)$. Namun demikian kadar glukosa darah akibat perlakuan $\mathrm{P}_{1}$ ini masih belum mendekati kadar glukosa darah tikus dalam kondisi normal yaitu $<105 \mathrm{mg} / \mathrm{dL}$ (Taguchi, 1985). Kelompok perlakuan $\mathrm{P}_{2}$ dengan dosis $100 \mathrm{mg} / \mathrm{kg} \mathrm{BB}$ memberikan kadar gula darah rata-rata sebesar $153.2 \pm 4.55$ $\mathrm{mg} / \mathrm{dL}$ atau penurunan kadar gula darah sebesar 236,6 $\mathrm{mg} / \mathrm{dL}$ bila dibandingkan dengan $\mathrm{K}(-)$, dan kelompok perlakuan $\mathrm{P}_{3}$ dengan dosis $200 \mathrm{mg} / \mathrm{kg}$ BB memberikan kadar gula darah rata-rata sebesar $110.2 \pm 5.22 \mathrm{mg} / \mathrm{dL}$ atau penurunan kadar gula darah sebesar 279,6 mg/dL bila dibandingkan dengan kelompok K(-). Jadi pemberian ekstrak etanol kulit batang buni dosis $200 \mathrm{mg} / \mathrm{kg}$ BB sampai akhir percobaan memberikan dampak paling mendekati kadar gula normal $(<105 \mathrm{mg} / \mathrm{dL})$.

Kelompok kontrol K(-) menunjukkan peningkatan kadar glukosa darah rata-rata yang cukup tinggi yang berarti semua tikus wistar telah mengalami kondisi hiperglikemia namun tidak ada pemberian obat antihiperglikemik ataupun ekstrak etanol kulit batang buni yang berfungsi sebagai penurun kadar glukosa darah pada kelompok ini. Pemberian atau induksi aloksan pada kelompok ini diduga telah menyebabkan kerusakan sel beta pankreas yang disebut dengan kondisi diabetes eksperimental atau efek diabetogenik. Sel beta pankreas merupakan tempat produksi hormon insulin yang berfungsi sebagai pengatur kadar glukosa darah dalam tubuh. Jika kadar glukosa tubuh berlebih maka akan terbentuk derivat radikal superoksida yang menyebabkan kerusakan sel tidak dapat diminimalisir sehingga terganggunya pembentukan hormon insulin, suatu hormon yang berfungsi sebagai pengatur kadar glukosa darah di dalam tubuh dengan cara mengubah glukosa menjadi glikogen yang disimpan di dalam hati. Akibat dari terganggunya pembentukan hormon insulin kadar glukosa darah semakin tidak terkendali dan semakin meningkat. (Zhang et al., 2009).
Hasil analisis statistik untuk melihat perbedaan antar perlakuan $\left(\mathrm{P}_{1}, \mathrm{P}_{2}\right.$, dan $\left.\mathrm{P}_{3}\right)$ dilakukan menggunakan uji KolmogorovSmirnov Test menunjukkan bahwa data terdistribusi normal dengan $p=0,4556 \quad(p>$ $0,05)$ dan homogen dengan $p=0,000(p<$ $0,05)$, sehingga memenuhi syarat untuk dianalisis menggunakan One-Way ANOVA. Uji ANOVA menunjukkan bahwa semua data kelompok perlakuan $\left(\mathrm{P}_{1}, \mathrm{P}_{2}\right.$, dan $\left.\mathrm{P}_{3}\right)$ berbeda secara signifikan dengan nilai $p=0,0000(p<$ $0,05)$ terhadap kontrol negatif $\mathrm{K}(-)$ yang artinya pemberian ekstrak etanol kulit batang buni pada dosis yang makin besar cenderung mengakibatkan penurunan kadar glukosa darah makin besar dan pada perlakuan $\mathrm{P}_{3}$ berdampak pada kadar gula darah rata-rata yang mendekati normal pada akhir percobaan (postest).

Hasil uji Tamhane menunjukkan bahwa kadar glukosa darah rata-rata antar kelompok perlakuan $\left(\mathrm{P}_{1}, \mathrm{P}_{2}\right.$, dan $\left.\mathrm{P}_{3}\right)$ berbeda secara bermakna $(p<0,05)$, yaitu $\mathrm{P}_{1}$ vs $\mathrm{P}_{2}$ $(p<0,05) ; \mathrm{P}_{1}$ vs $\mathrm{P}_{3}(p<0,05)$, dan $\mathrm{P}_{2}$ vs $\mathrm{P}_{3}$ $(p<0,05)$, artinya semakin meningkat dosis ekstrak etanol kulit batang buni yang diberikan kepada hewan coba tikus wistar berdampak pada penurunan kadar gula darah rata-rata yang makin besar. Namun demikian pemberian ekstrak etanol kulit batang buni dosis 200 $\mathrm{mg} / \mathrm{kg}$ BB (kelompok perlakuan $\mathrm{P}_{3}$ ) sampai akhir percobaan (postest) memberikan kadar glukosa darah rata-rata sebesar $110.2 \mathrm{mg} / \mathrm{dL}$ paling mendekati kadar gula darah tikus dalam kondisi normal $(<105 \mathrm{mg} / \mathrm{dL})$.

\section{Senyawa dalam Ekstrak Etanol Kulit Batang Buni}

Penurunan kadar glukosa darah pada hewan coba diduga karena aktivitas antioksidan komponen senyawa kimia yang terdapat di dalam ekstrak kulit batang buni yaitu limonen (Roberto et al., 2009), undekadiena (Kim et al., 2014), d-nerolidol (Chan et al., 2016), dan kariofilen (Dahham et $a l ., 2015)$ karena diduga senyawa-senyawa ini mampu menangkap radikal bebas dalam proses kerusakan sel beta pankreas. Gambar 2 menunjukkan puncak-puncak senyawa dalam ekstrak etanol kulit batang buni dianalisa menggunakan metode KG-SM. 


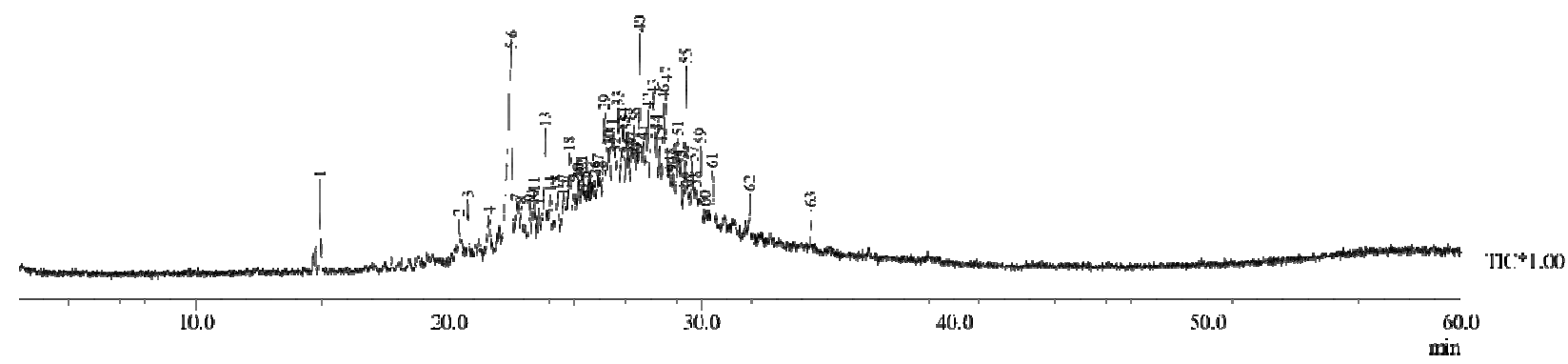

Gambar 2. Kromatogram senyawa dalam ekstrak etanol kulit batang buni

\section{SIMPULAN DAN SARAN}

\section{Simpulan}

Ekstrak etanol kulit batang buni (Antidesma bunius L. Spreng) dosis $200 \mathrm{mg} / \mathrm{kg}$ BB efektif dalam menurunkan kadar glukosa darah tikus wistar hiperglikemia dengan penurunan mendekati kadar glukosa darah normal.

\section{Saran}

Berdasarkan penelitian yang telah dilakuan, dapat disarankan bahwa perlu adanya isolasi dan identifikasi lebih lanjut pada senyawa yang terdapat di dalam kulit batang buni dengan menggunakan metode kromatografi lainnya untuk mengetahui struktur senyawa yang berpotensi sebagai agen antihiperglikemia.

\section{UCAPAN TERIMAKASIH}

Penulis mengucapkan terimakasih pihak yang telah membantu dalam proses pembuatan karya ilmiah ini.

\section{DAFTAR PUSTAKA}

Atalay, M., and Laaksonen, D.E. 2002. Diabetes, oxidative stress and physical exercise. Journal of Sports Science and Medicine. 1: 1-14.
Chan, WC., Tan., L.T.H.T., Chan, KG., Lee, L.H., and Goh, B.H. 2016. Nerolidol: A Sesquiterpene Alcholol with MultiFaceted Pharmalogical and Biological Activities. Journal Molecules. 21 (529): 1-40.

Dahham, S.S., Tabana, Y.M., Iqbal, M.A., Ahamed, M.B.K., Ezzat, M.O., Majid., A.S.A., and Majid, A.M.S.A. 2015. The Anticancer, Antioxidant and Antimicrobial Properties of the Sesquiterpene $\beta$-Caryophyllene from the Essential Oil of Aquilaria crassna. Journal Molecules. 20: 11808-29.

Elya, B., Malik, A., dan Mahanani, P. I. S. 2012. Antidiabetic Activity Test by Inhibition of $\alpha$-Glucosidase and Phytochemical Screening from the Most Active Fraction of Buni (Antidesma bunius L.) Steam Barks and Leaves. International Journal of PharmTech Research. 4(4): 16671671.

Gosh, D and Konishi, T. 2007. Anthocyanin and anthocyanin-rich extracts: role in diabetes and eye function. Asia Pasific Journal of Clinical Nutrition. 16 (2).

Herera, S. M. D., Panopi, A. M., Pedrezuela, H. J. C., Perez, R. F., \& Dumaoal, O. S. R. 2010. Antiglycemic Effect of Bignay (Antidesma bunius L.) Flavanoids in Sprague-Dawley Rats. Lyceum of the Philippines University. Batangas City. 
Lau, A. and Harper, W. 2007. Thiazolidinediones and their effect on bone metabolism: a review. Canadian journal of diabetes. 31(4): 378-383.

Kiec, A., Mykkanen, O., Wilk, B. and Mykkanen, H. 2008. Antioxidant phytochemicals against type 2 diabetes. The British Journal of Nutrition. 99.

Kim, M.K., Nam, P.W., Lee, S.J., and Lee, K.G. 2014. Antioxidant activities of volatile and non-volatile actions of selected traditionally brewed Korean rice wines. Journal Institute of Brewing \& Distiling. 120:537-42.

Kwon, O., Eck, P., Chen, S., Corpe, C.P., Kruhlak, J. L., and Levine, M. 2007. Inhibiton of intenstinal glucose transporter GLUT2 by flavonoids. Federation of American Societies for Experimental Biology. 21 (2).

Roberto, D., Micucci, P., Sebastian, T., Graciela, F., and Anesini, C. 2009. Antioxidant Activity of Limonene on Normal Murine Lymphocytes: Relation to $\mathrm{H}_{2} \mathrm{O}_{2}$ Modulation and Cell Proliferation. Journal Compilation Nordic Pharmacological Society. Basic \& Clinical Pharmacology \& Toxicology. 106: (38-44).

Sumadewi, N.L.U. 2011. Isolasi Senyawa Tanin dan Uji Efek Hipoglikemik
Ekstrak Kulit Batang Bungur (Lagerstroemia speciosa Pers.) terhadap Darah Mencit yang Diinduksi Aloksan. Tesis. Program Pascasarjana, Universitas Udayana.

Suryabrata, S. 2011. Metodologi Penelitian, Jakarta: PT. Raja Grafindo Persada.

Taguchi, Y. 1985. Experimental Animals. Clea Japan, Inc. Tokyo.

Widowati, Wahyu. 2008. Potensi Antioksidan sebagai Antidiabetes. Journal Kristen Maranatha. 7 (2): 1-11.

Wild, S., Roglic, G., Green, A., Sicree, R., and King, H. 2004. Global Prevalence of Diabetes. Diabetes Care. 27: 10471053.

Wisudanti, D. D. 2016. Kajian Pustaka: Aplikasi Terapeutik Geraniin Dari Ekstrak Kulit Rambutan (Nephelium Lappaceum) Sebagai Antihiperglikemik Melalui Aktivitasnya Sebagai Pada Diabetes Melitus Tipe 2. Nurse Line Journal. 1(1): 120-38.

Zhang, Z., Jiang, J., Yu, P., Zeng, X., Larrick, J.W., and Wang, J. 2009. Hypoglygemic and Beta Cell Protective Effects of Andrograholide Analogue for Diabetes Treatmen. Journal of Translational Medicine. 7: 62. 